\title{
Role of Yeasts in the Brewing Process: Tradition and Innovation
}

\author{
Massimo Iorizzo $^{1} \mathbb{D}$, Francesca Coppola ${ }^{2} \mathbb{D}$, Francesco Letizia ${ }^{1}$, Bruno Testa ${ }^{1, *}$ and Elena Sorrentino ${ }^{1} \mathbb{D}$ \\ 1 Department of Agricultural, Environmental and Food Sciences (DiAAA), University of Molise, via De Sanctis snc, \\ 86100 Campobasso, Italy; iorizzo@unimol.it (M.I.); f.letizia@studenti.unimol.it (F.L.); sorrentino@unimol.it (E.S.) \\ 2 Department of Agricultural Sciences, Grape and Wine Science Division, University of Naples "Federico II", \\ Viale Italia, 83100 Avellino, Italy; fracop93@libero.it \\ * Correspondence: bruno.testa@unimol.it; Tel.: +39-0874-404622
}

Citation: Iorizzo, M.; Coppola, F.; Letizia, F.; Testa, B.; Sorrentino, E. Role of Yeasts in the Brewing Process: Tradition and Innovation. Processes 2021, 9, 839. https://doi.org/ $10.3390 /$ pr9050839

Academic Editor: Antonio D. Moreno

Received: 27 April 2021

Accepted: 8 May 2021

Published: 11 May 2021

Publisher's Note: MDPI stays neutral with regard to jurisdictional claims in published maps and institutional affiliations.

Copyright: (c) 2021 by the authors. Licensee MDPI, Basel, Switzerland. This article is an open access article distributed under the terms and conditions of the Creative Commons Attribution (CC BY) license (https:// creativecommons.org/licenses/by/ $4.0 /)$.

\begin{abstract}
Nowadays, in the beer sector, there is a wide range of products, which differ for the technologies adopted, raw materials used, and microorganisms involved in the fermentation processes. The quality of beer is directly related to the fermentation activity of yeasts that, in addition to the production of alcohol, synthesize various compounds that contribute to the definition of the compositional and organoleptic characteristics. The microbrewing phenomenon (craft revolution) and the growing demand for innovative and specialty beers has stimulated researchers and brewers to select new yeast strains possessing particular technological and metabolic characteristics. Up until a few years ago, the selection of starter yeasts used in brewing was exclusively carried out on strains belonging to the genus Saccharomyces. However, some non-Saccharomyces yeasts have a specific enzymatic activity that can help to typify the taste and beer aroma. These yeasts, used as a single or mixed starter with Saccharomyces strains, represent a new biotechnological resource to produce beers with particular properties. This review describes the role of Saccharomyces and non-Saccharomyces yeasts in brewing, and some future biotechnological perspectives.
\end{abstract}

Keywords: brewing; Saccharomyces; non-Saccharomyces; non-conventional yeasts

\section{Introduction}

Beer is a fermented alcoholic beverage which has been produced for thousands of years, and it is consumed worldwide. Beer is obtained by the fermentation of yeasts of a must consisting of water, malted cereals (usually barley and wheat), and hops. The brewing process basically includes the following stages: malting (in which cereal is converted into malt), mashing (during this phase the malt enzymes convert the grain starches into fermentable sugars), alcoholic fermentation and maturation.

The main stages in the brewing process are: wort production, alcoholic fermentation and maturation, processing, and stabilization of the beer.

The wort transforms into beer during alcoholic fermentation and maturation, which are the longest processes in brewing. The primary fermentation lasts between 3 and 6 days, and the maturation up to 2 weeks depending on the fermentation type and the equipment used. Ethanol fermentation occurs as a result of enzymatic activity of the yeast at the Embden-Meyerhof-Parnas pathway, which leads to glucose conversion to pyruvate. Under anaerobic conditions, the yeasts convert pyruvate to ethanol and $\mathrm{CO}_{2}$. In aerobic conditions, yeasts consume sugars, mainly for biomass accumulation and $\mathrm{CO}_{2}$ production.

The yeasts uptake the carbohydrates of wort in a specific sequence: monosaccharides (glucose and fructose), disaccharides (sucrose and maltose), and trisaccharide maltotriose, and ferment them in the same order. A very small amount of maltotriose is used for the formation of reserve polysaccharides (glycogen and trehalose). The amino acids assimilated by yeast are used for the synthesis of proteins, enzymes, and new cells. The fermentation byproducts: carbonyl compounds, higher alcohols, esters, organic acids, and sulfur-containing compounds determine the flavor profile and affect the quality of the beer. 
However, to obtain high quality and competitive products on the market, different scientific disciplines are involved in the brewing process: microbiology, chemistry, agronomy, logistics, marketing, engineering, and health sciences (Figure 1) [1].
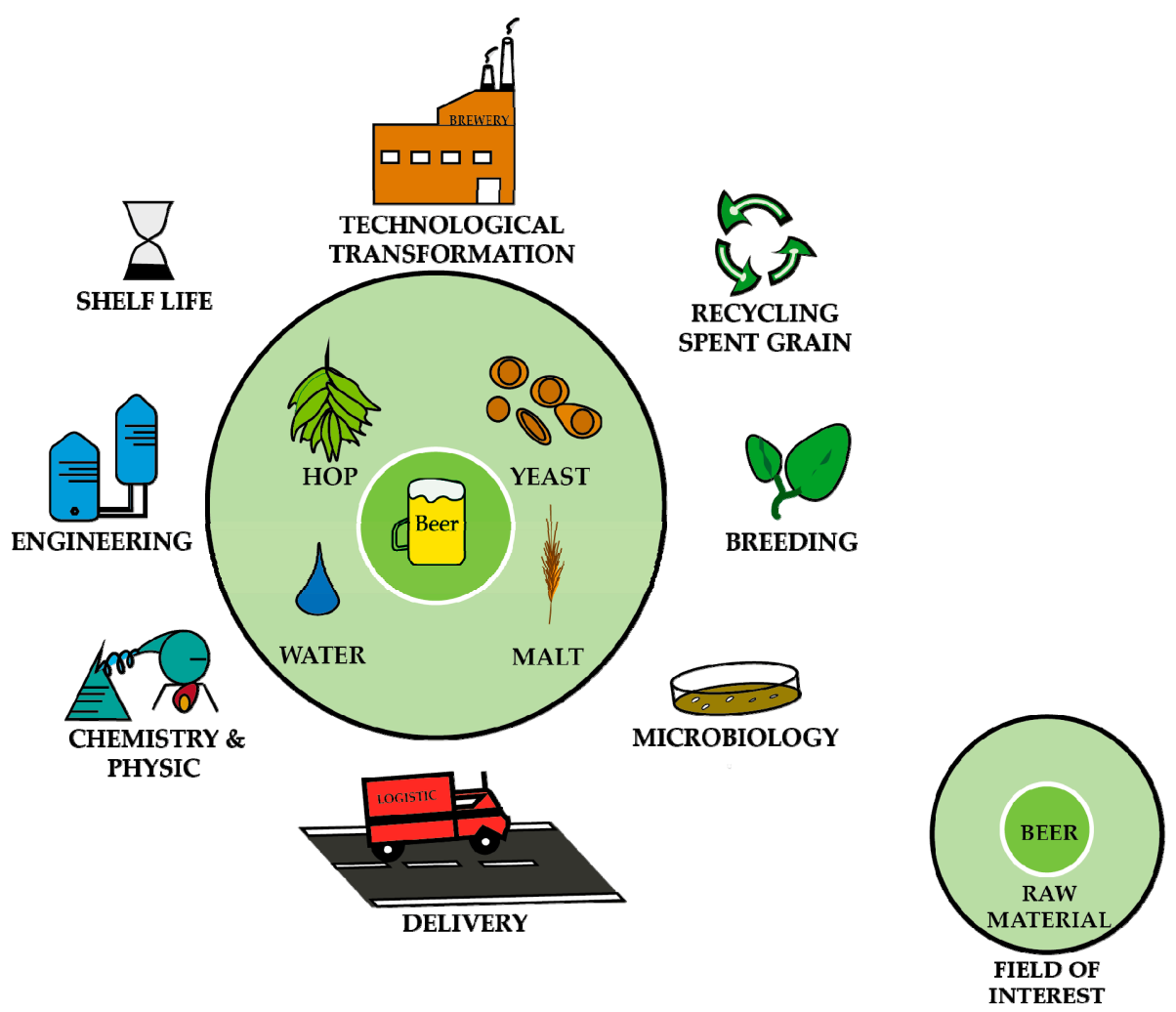

Figure 1. The main ingredients for brewing (center) and the main disciplines involved in the brewing world (outer part), and their interactions. Adapted from Iattici et al., 2020 [1].

The Saccharomyces yeasts, involved in alcoholic fermentation processes, play a decisive role in the organoleptic characterization of the products [2].

For large-scale beverage fermentation, as in brewing, winemaking, and distilled spirit production, pure cultures of selected strains of Saccharomyces spp. are usually used, whereas in smaller-scale (artisanal) processes, spontaneous fermentation is often developed by indigenous microflora found in the raw material [3].

The Saccharomyces genus contains some important species for the food industry, namely, Saccharomyces cerevisiae (used in winemaking and ale beer brewing), Saccharomyces bayanus (used in winemaking and cider production), and Saccharomyces pastorianus (used in lager beer brewing) [4].

Ale, lager, porter, stout, lambic, weiss, and many other denominations accompany the term "beer" to indicate specific brewery products with unique organoleptic and chemical properties.

The diversity of beers has been obtained because producers have often maintained local traditions which have yielded products with distinctive characteristics linked to the native territory [5]. In recent years, the diversity of products has increased with the rise of smaller breweries creating bespoke beers. This worldwide economic phenomenon has been called the "craft beer revolution" [6-8]. Initially, only two types of yeasts were used, selecting them according to the ability to flocculate: top fermenting (ale yeast) [9] and bottom fermenting (lager yeast) [4].

Currently, the main criterion accepted for beer classification relies on the brewing process, which divides it into three macro-categories: ale, lager, and lambic beers. 
Ale beer is brewed by using $S$. cerevisiae strains, while lager-style beer involves S. pastorianus strains, and lambic-style beer is obtained from spontaneous fermentation of indigenous yeasts present in the raw materials used [10].

Today, modern brewers tend to use new ingredients, including spices, herbs, and fruits, to enhance the flavor. However, yeasts still have the main role in defining the organoleptic characteristics of beer [11].

Up until a few years ago, the selection of starter yeasts, used in beer production, was exclusively carried out on strains belonging to the genus Sacharomyces; this is because these yeasts were predominant in spontaneous fermentations $[2,12,13]$.

In contrast, non-Saccharomyces yeasts have often been ignored, both because they are not very predominant in the fermentation process and also because of their high production of off-flavor compounds, such as acetic acid, diacetyl, and 2,3-butanediol [14,15]. Despite this, the rising demand of new specialty beers has driven researchers to isolate and reevaluate the potential benefits of non-Saccharomyces yeasts in beer production.

Non-Saccharomyces yeasts possess, unlike Saccharomyces yeasts, many enzymatic activities which can lead to the production of metabolites that contribute to a greater aromatic complexity of alcoholic beverages [16-19].

Michel et al. [11] and Basso et al. [12] emphasized the great potential of non-Saccharomyces yeasts to develop beers with different alcohol contents and a broad range of flavors. They highlighted the varying abilities of unconventional yeasts to metabolize desirable aroma-active substances, such as fruity esters, monoterpenes, higher alcohols, phenols, and acids.

In beer, the production of flavor-active compounds is strictly strain-dependent [20]. Thus, the choice of yeast strains used in beer production is essential to obtain products with desirable and distinctive sensory properties.

\section{Saccharomyces Yeasts in the Brewing Process}

The Saccharomyces "sensu stricto" group is composed of eight biologically distinct yeast species, namely S. cerevisiae, S. paradoxus, S. cariocanus, S. uvarum, S. mikatae, S. kudriavzevii, S. arboricola, and S. eubayanus, and two natural hybrids, namely S. pastorianus and S. bayanus [21,22].

In the beer sector, the genus Saccharomyces can traditionally be divided into two groups: ale and lager yeasts, also known as the top-fermenting and bottom-fermenting yeasts, respectively [23]. This differentiation was originally made because the strains were classified on the basis of their flocculation property. S. cerevisiae traditionally conducts "top fermentation" where yeasts aggregate on the surface of the fermenting wort.

Traditionally, S. pastorianus, hybrids of S. cerevisiae and S. bayanus [4], is the yeast used for lager-style beer fermentations. This facilitates the harvesting and cropping of yeasts from fermented must and can be used as a starter in subsequent fermentations $[3,24]$.

Lager represents almost $90 \%$ of the beer market; ale beer represents $5 \%$ of the beer market [15]. The remaining percentage is taken by beers produced by spontaneous fermentation with indigenous yeasts and bacteria $[25,26]$. Ale beers are brewed by $S$. cerevisiae strains at a fermentation temperature of $15-25^{\circ} \mathrm{C}$, while lager-style beer involves $S$. pastorianus strains in a process conducted at a temperature of $8-12{ }^{\circ} \mathrm{C}$ [1]. In all cases, a positive result depends on the choice of the yeast strain used and its vigor and vitality.

The process control parameters, such as sufficient nutrient supply, correct inoculation (pitching) rate, optimized dissolved oxygen addition, and temperature control, are important for proper yeast metabolic activity and for beer quality [27].

The production of quality beer relies on the activity of fermenting yeasts that are qualified not only for good fermentation yield efficiency, but also for affecting aroma and flavor of the beverage.

The volatile part of the beer includes over 800 different compounds, but only some of them are known to be active for flavor [28,29]. A large part of these compounds, dissimilar to the aromatic compounds present in malt and hops, are synthesized during alcoholic fermentation and have an important impact on the aroma and taste of beer [30]. 
In Table 1, some classes of metabolites produced by Saccharomyces yeasts during alcoholic fermentation, the main compounds that characterize the classes, and their principal influence on the sensorial characteristics of the beers have been reported.

The production and quantity of these compounds depend on the yeast strains involved in the fermentation process and, therefore, their choice is of fundamental importance [3,30-39]. In addition to the traditional S. pastorianus and S. bayanus natural hybrids strains $[4,40]$ that have been used extensively by the brewing industry [23], the recent discovery of S. eubayanus [41] has allowed the creation of brewing yeast hybrids generated by de novo hybridization [42-48].

Table 1. Secondary metabolites production during alcoholic fermentation by Saccharomyces.

\begin{tabular}{|c|c|c|c|}
\hline Metabolite Class & Principal Compounds & Comments & References \\
\hline Higher alcohols & $\begin{array}{l}\text { amyl alcohol, n-propanol, } \\
\text { isobutanol, isoamyl alcohol, } \\
\text { 2-phenylethanol }\end{array}$ & $\begin{array}{l}\text { Higher alcohols can contribute floral, fruity or } \\
\text { herbal aromas. Amyl alcohol (alcoholic, } \\
\text { solvent), n-propanol (Alcohol, sweet), } \\
\text { isobutanol (solvent), isoamyl alcohol } \\
\text { (Alcoholic, banana), 2-phenylethanol (Roses). }\end{array}$ & {$[29,49-51]$} \\
\hline Esters & $\begin{array}{l}\text { ethyl acetate, isoamyl acetate, } \\
\text { isobutyl acetate phenylethyl acetate, } \\
\text { ethyl hexanoate and ethyl octanoate }\end{array}$ & $\begin{array}{l}\text { They contribute to a wide range of fruity } \\
\text { flavors to the composition of fermented } \\
\text { beverages. Ethyl acetate (solvent-like aroma), } \\
\text { isoamyl acetate (banana aroma), isobutyl } \\
\text { acetate (fruity aroma), phenylethyl acetate } \\
\text { (roses and honey aroma), ethyl hexanoate } \\
\text { (sweet apple aroma) and ethyl octanoate (sour } \\
\text { apple aroma). }\end{array}$ & {$[29,49-51]$} \\
\hline Carbonyls & $\begin{array}{l}\text { acetaldehyde, diacetyl, } \\
\text { 2,3-pentanedione }\end{array}$ & $\begin{array}{l}\text { Excessive concentrations of acetaldehyde } \\
\text { carbonyl compounds cause stale flavor in beer } \\
\text { and impart an undesirable "cut grass" or } \\
\text { "green apple" character. Diacetyl contributes } \\
\text { negatively with a buttery flavor to the beer }\end{array}$ & {$[49,51]$} \\
\hline Organic acids & $\begin{array}{l}\text { Succinic, citric, acetic, malic and } \\
\text { pyruvic acids }\end{array}$ & $\begin{array}{l}\text { The balance between sourness and sweetness } \\
\text { of a beer is of great importance. }\end{array}$ & {$[52,53]$} \\
\hline Polyols & Glycerol & Contribute to the smoothness & [49] \\
\hline Sulphur compounds & $\begin{array}{l}\text { Hydrogen sulphide, Dimethyl } \\
\text { sulphide, Sulphur dioxide, Thiols }\end{array}$ & $\begin{array}{l}\text { Small amounts of sulphur compounds can be } \\
\text { acceptable, or even desirable in some beers, in } \\
\text { excess they give rise to unpleasant off-flavors. }\end{array}$ & {$[49,50]$} \\
\hline
\end{tabular}

Saccharomyces interspecific hybrids, both artificial and natural, have a significant potential in industry. This is because they, compared to parents, often show the synergistic phenomenon of heterosis, also called hybrid vigor, which is the tendency to outperform parents in fermentative performances. $[47,48,54]$. In this context, the hybridization of Saccharomyces brewing yeasts, besides improving fermentation efficiency, also offers the possibility of generating novel non-genetically modified (non-GM) strains with unique properties [47,55]. In fact, many studies on yeast hybrids have focused on attempting to increase the formation and diversity of aroma-active compounds in beer. Table 2 shows studies published on the use of Saccharomyces hybrids in brewing.

These studies have been mainly limited to hybrids created with S. cerevisiae, S. bayanus, and S. eubayanus strains as parents. Many other species in the Saccharomyces genus possess traits desirable for brewing, including cold tolerance and high ester formation, and thus represent feasible alternatives to $S$. eubayanus in interspecific hybrids for lager brewing purposes $[48,56]$. 
Table 2. Studies published on the use of Saccharomyces hybrids in brewing.

\begin{tabular}{|c|c|c|}
\hline Species & Comments & References \\
\hline S. cerevisiae ale/S. cerevisiae sake & $\begin{array}{l}\text { Beer brewed using hybrids contained more ethanol and } \\
\text { esters compared to beer brewed using the parent strains. }\end{array}$ & {$[57]$} \\
\hline $\begin{array}{l}\text { S. cerevisiae ale/S. cerevisiae } \\
\text { (syn S. cerevisiae var. diastaticus) }\end{array}$ & $\begin{array}{l}\text { Hybrid had higher osmotolerance and higher ethanol yield } \\
\text { than the parent strain. }\end{array}$ & [58] \\
\hline S. cerevisiae ale/Cold-tolerant S. bayanus & $\begin{array}{l}\text { Hybridization with S. bayanus is useful to improve } \\
\text { low-temperature fermentability of the top-fermenting yeast } \\
\text { S. cerevisiae. }\end{array}$ & [59] \\
\hline S. cerevisiae ale/S. bayanus & $\begin{array}{l}\text { Hybrid strains, compared to the lager parent strain, showed } \\
\text { improved stress resistance (osmo- and temperature } \\
\text { tolerance), fermentation performance and improved } \\
\text { survival at the end of fermentation. }\end{array}$ & {$[60]$} \\
\hline S. cerevisiae, S. paradoxus, and S. pastorianus & $\begin{array}{l}\text { Some hybrids show a distinct heterosis (hybrid vigor) effect } \\
\text { and produce greater quantities of isoamyl acetate than the } \\
\text { best parental strains, while retaining their overall } \\
\text { fermentation performance. }\end{array}$ & {$[61]$} \\
\hline S. cerevisiae/S. eubayanus & $\begin{array}{l}\text { The hybrid had improved tolerance to low temperatures } \\
\text { and the capacity of oligosaccharide utilization, compared to } \\
\text { the parent strains. }\end{array}$ & [43] \\
\hline S. cerevisiae/S. eubayanus & $\begin{array}{l}\text { Hybrids inherited beneficial properties from both parent } \\
\text { strains (cryotolerance, maltotriose utilization and strong } \\
\text { flocculation) and showed apparent hybrid vigor, fermenting } \\
\text { faster and producing beer with higher alcohol content than } \\
\text { the parent strains. }\end{array}$ & {$[44]$} \\
\hline S. cerevisiae ale and wine strains/S. eubayanus & $\begin{array}{l}\text { Hybrids produced a greater diversity of aroma compounds } \\
\text { compared to traditional lager yeast and parent strains. }\end{array}$ & [46] \\
\hline S. cerevisiae ale strain/S. eubayanus type strain & $\begin{array}{l}\text { Some hybrids showed increased fermentation rates and } \\
\text { produced higher concentration of flavor-active esters. }\end{array}$ & [45] \\
\hline S.cerevisiae/S.uvarum & $\begin{array}{l}\text { The hybrid strain possesses a range of industrially desirable } \\
\text { phenotypic properties, including broad temperature } \\
\text { tolerance, good ethanol tolerance, and efficient } \\
\text { carbohydrate use. }\end{array}$ & [56] \\
\hline
\end{tabular}

\section{Non-Saccharomyces Yeasts in the Brewing Process}

It is generally assumed that non-Saccharomyces yeasts play a negative role in the brewing process resulting in problems associated with beer turbidity, filterability, viscosity, phenolic off-flavors, and other negative flavor profile changes [39]. However, in recent years, the selection and use of non-Saccharomyces yeasts has been a biotechnological resource in brewing $[62,63]$. In fact, in some cases, the use of these yeasts allows, in addition to some technological advantages, also an improvement and diversification of the sensory profile of the beers $[12,64]$. For example, the characteristic lambic beer sensory profile is caused by spontaneous fermentations of non-Saccharomyces yeasts, including, in particular, Brettanomyces bruxellensis strains. These yeasts, besides having a high volatile acidity, also produce esters, such as ethyl acetate, ethyl caprate, ethyl caprylate, and ethyl lactate, which characterize the typical sour flavor of lambic beer [10,65-68].

Non-Saccharomyces yeasts have low primary metabolic efficiency, which end up having a limited fermentation performance. However, compared to Saccharomyces, they possess greater enzymatic capacities and metabolic pathways for the synthesis of volatile compounds that contribute to the flavor and aromatic profile of the final product $[12,17-19,69,70]$.

In addition to the compounds which are formed during the alcoholic fermentation, monoterpene alcohols (linalool, $\alpha$-terpineol, $\beta$-citronellol, geraniol, and nerol) derived 
from hops contribute to the sensory characteristics of beer. In wort, these compounds are often present in glycosidically bound forms and aromatically inactive [71]. Some nonSaccharomyces yeasts have beta-glucosidase, an important enzyme for the hydrolysis of glycoconjugate precursors and the release of active aromatic compounds [72].

With the spread of the microbrewing phenomenon (craft revolution), in recent years, there has been a growing interest in innovation and production of beers with greater sensory complexity. The selection and use of unconventional yeasts allow the production of distinctive products that are not included in the traditional beer on offer and, at the same time, can satisfy new consumer trends. [65].

Often non-Saccharomyces yeasts are found in spontaneous beer fermentation and, in some cases, used as starter cultures for brewing. Most of them belong to the following genera: Brettanomyces, Candida, Debaryomyces, Hanseniaspora, Kazachstania, Kluyveromyces, Lachancea, Metschnikowia, Meyerozyma, Pichia, Rhodotorula, Starmerella, Saccharomycodes, Saccharomycopsis, Torulaspora, Trichosporon, Wickerhamomyces, Williopsis, Yarrowia, Zygoascus, and Zygosaccharomyces. [73-77]. Compared to spontaneous fermentation, the use of mixed starters, composed of S. cerevisiae and non-Saccharomyces selected strains, represents an interesting strategy to obtain an aromatic complexity, enhance desirable characteristics, and reduce or eliminate off-flavors [77].

The effect of pure or mixed starters, using Saccharomyces and non-Saccharomyces strains in beer production, has also been examined [26,35]. Some metabolic products and their main impacts on beer composition of non-Saccharomyces starter are summarized in Table 3.

However, unlike the wine sector, where non-Saccharomyces commercial starters (Torulaspora delbrueckii, Metschnikowia pulcherrima, Metschnikowia fructicola, Kluyveromyces thermotolerans, Kluyveromyces wickerhamii, Candida zemplinina, Schizosaccharomyces pombe, and Pichia kluyveri) are now widely used for innovative applications [78], the commercial offer in the beer sector is very limited. In fact, of all the yeasts mentioned, only a few strains belonging to the genus Brettanomyces spp. are available as non-Saccharomyces commercial starters. Due to the limited supply, a recent study assessed the effect of non-Saccharomyces yeast strains selected and marketed for the wine sector, in beer fermentation [79]. In breweries and wineries, Brettanomyces are typically recognized as spoilage yeasts, being the cause of major economic losses. Its presence can completely change the organoleptic properties of the product, creating a controversial characteristic, which is mainly due to the production of secondary metabolites when performing alcoholic fermentation. These metabolites have been associated with undesirable flavors, depicted as horse sweat, barnyard, medicinal, or leathery. However, used appropriately, Brettanomyces can contribute to fruit flavors (e.g., pineapple, mango, pear, grape, lemon) and, today, they are often used in craft beers. Over the last decade, the craft beer sector has constantly demanded novel attractive flavors, and there has been a rising interest in understanding Brettanomyces species, exploiting its potential in beer fermentation $[66,67,80,81]$. The species most commonly marketed for the beer sector belongs to the $B$. bruxellensis species, which is proposed as a pure crop or in mixed cultures with B. lambicus, B. anomalus, B. claussenii, B. nanus, B. naardenensis, and B. custersianus or with Lactobacillus and Pediococcus strains for sour beer production [82]. These cultures also produce large amounts of ethyl lactate and ethyl acetate, along with some acetic acid, but the commercial success is mainly due to their high $\beta$-glucosidase activity that allows the release of monoterpene aromatic alcohols from hops, enhancing "flowery" and "citrus" characteristics in the beer. 
Table 3. Principal impacts on beer composition of non-Saccharomyces.

\begin{tabular}{|c|c|c|}
\hline Species & Comments & References \\
\hline Brettanomyces bruxellensis/Dekkera bruxellensis & $\begin{array}{l}\text { Significant esters production: ethyl acetate, } \\
\text { ethyl caprate, ethyl caprylate and ethyl lactate. }\end{array}$ & {$[66-68,73,75,83-89]$} \\
\hline Debaryomyces hansenii & $\begin{array}{l}\text { Significant production of glycerol, acetic acid, } \\
\text { ethanol, isoamyl alcohol, hexanol, isoamyl } \\
\text { acetate, ethyl octanoate, ethyl hexanoate }\end{array}$ & {$[86,87,90]$} \\
\hline Lachancea thermotolerans & $\begin{array}{l}\text { Low acetic acid and high lactic acid and } \\
\text { glycerol productions. }\end{array}$ & {$[87,91,92]$} \\
\hline Pichia kluyveri & $\begin{array}{l}\text { Low ethanol production with significant } \\
\text { production of isoamyl acetate, isoamyl alcohol, } \\
\text { ethyl butyrate, ethyl hexanoate, and } \\
\text { ethyloctanoate, ethyl acetate }\end{array}$ & {$[84,87,93-95]$} \\
\hline Saccharomycodes ludwigii & $\begin{array}{l}\text { Low production of ethanol, significant } \\
\text { production of ethyl acetate, isoamyl acetate } \\
\text { and 4-vinylguaiacol, but high quantities of } \\
\text { amyl alcohols and higher alcohols }\end{array}$ & [96-98] \\
\hline Torulaspora delbrueckii & $\begin{array}{l}\text { Ethanol up to } 9-11 \% v / v \text {, significant } \\
\text { production of } \beta \text {-phenylethanol, n-propanol, } \\
\text { iso-butanol, amyl alcohol, and ethyl acetate, } \\
\text { ability to convert hop monoterpene alcohols } \\
\text { into linalool }\end{array}$ & {$[12,73-75,87,99-103]$} \\
\hline Wickerhamomyces anomalus & $\begin{array}{l}\text { Low ethanol and significant production of } \\
\text { ethyl propanoate, phenyl ethanol, } \\
\text { 2-phenylethyl acetate, and ethyl acetate }\end{array}$ & {$[12,86-88]$} \\
\hline Zygosaccharomyces rouxii & $\begin{array}{l}\text { Low ethanol and significant production of } \\
\text { ethyl acetate, amyl alcohols, isoamyl alcohols, } \\
\text { and other esters and higher alcohol }\end{array}$ & {$[98,104]$} \\
\hline Hanseniaspora guilliermondii, Hanseniaspora opuntiae & $\begin{array}{l}\text { Significant production of ethyl acetate and } \\
\text { phenylethyl acetate, producing a beer with a } \\
\text { pleasant 'honey' aroma }\end{array}$ & [105] \\
\hline Williopsis saturnus var. mrakii & $\begin{array}{l}\text { Low ethanol with higher levels of acetate } \\
\text { esters, terpenes and terpenoids }\end{array}$ & [106] \\
\hline Cyberlindnera fabianii and Pichia kudriavzevii & $\begin{array}{l}\text { Low ethanol production, decrease in high } \\
\text { alcohols and volatile esters (ethyl acetate, } \\
\text { 3-methylbutyl acetate, methylpropyl acetate, } \\
\text { phenylethyl acetate, ethyl hexanoate and ethyl } \\
\text { octanoate) compared to S. cerevisiae }\end{array}$ & [107] \\
\hline Pichia anomala and Zygoascus meyerae & $\begin{array}{l}\text { Production of aromatic compounds such as } \\
4 \text {-vinylguaiacol, } \beta \text {-phenylethyl alcohol and } \\
\text { isoamyl alcohol }\end{array}$ & [26] \\
\hline Hanseniaspora vineae & $\begin{array}{l}\text { Low- alcohol and high esters production (in } \\
\text { particular, 2-phenylethyl acetate) }\end{array}$ & [26] \\
\hline Candida tropicalis & $\begin{array}{l}\text { Higher alcohols and acetaldehyde, low amount } \\
\text { of succinate and lactate, and reduced } \\
\text { aroma-active compounds. }\end{array}$ & {$[108,109]$} \\
\hline Mrakia gelida and Mrakia blollopis & $\begin{array}{l}\text { Low-alcohol production; sensory profile } \\
\text { fruitier }\end{array}$ & [110] \\
\hline Candida zemplinina & Higher ethanol production & {$[111,112]$} \\
\hline
\end{tabular}




\section{Role of Yeasts in Specialty Beers Production}

\subsection{Low-Alcohol Beer}

Over the last years, the consumption of alcohol-free beer has risen significantly due to the fact that it represents an alternative to standard soft drinks. The expansion of the beer industry into new markets (e.g., beer production in countries where alcohol consumption is banned) could motivate researchers to look for new strategies to reduce alcohol content in beer. There is an increasing interest of consumers in health issues, and no alcohol policies for drivers and pregnant women [110]. Beers with reduced alcohol content are often classified as "low-alcohol" beers containing 1.2\% v/v of ethanol, and "non-alcohol" or "alcohol-free" beers containing $0.5 \% v / v$ of ethanol [113]. However, most of the nonalcoholic beers available have a flavor profile that is not well accepted [114-116]. These beers can be produced through a physical process, involving ethanol removal from beer, or a biological process, based on limited ethanol formation during beer fermentation [117]. Physical methods include: vacuum rectification and evaporation, spinning cone column distillation, osmotic distillation, dialysis, and reverse osmosis [118,119]. This method requires considerable investments in the special equipment for alcohol removal, and the final beer is characterized by poor sensory qualities caused by losing higher alcohols and esters [96]. The aim of the other method, often referred to as biological, is to reduce alcohol production during the fermentation process. In general, in the biological processes of obtaining low alcoholic beer, the wort is not completely fermented, either with the interruption of fermentation, cold fermentation, immobilization of yeast, or use of nonconventional yeast $[113,120-124]$. The great challenge presented to all breweries that produce non-alcoholic beers is to develop products that have organoleptic characteristics that are as close as possible to the original beers and, thus, present a greater acceptance by consumers [114]. In this sense, non-conventional yeasts, unable to utilize maltose and/or maltotriose, represent a very interesting alternative to classical physical methods, both for the lower production costs and for the advantage of producing low-alcohol beers with an aromatic complexity similar to that of standard beers $[12,55,75,113]$. An example of this is the use of S. ludwigii in brewing $[97,98,125]$. Beer produced with this yeast contains very low alcohol concentration and shows high amounts of esters that contribute to a "fruity" characteristic [98]. Similarly, beer brewed with strains of P. kluyveri and T. delbrueckii that cannot degrade maltose could be an interesting way to produce beers with a lower alcohol content but rich in flavor and fruity aroma. In Table 4, some non-Saccharomyces species tested for low-alcohol beer production with the relative references are reported. Beers produced using this strategy contained a more complex flavor profile compared to single fermentations with S. cerevisiae and, in some cases, lower alcohol content $[87,126]$.

Recently, gene modification (GM) approaches have been used to generate a yeast strain able to produce a low alcohol beer with rich fruity flavor and aroma. Considering the negative public perception toward genetically modified organisms (GMO) and that the legislation in various countries restricts the sale of products containing either GMO or GMO in their manufacture, no GM approaches have been developed for the generation of beer yeasts that produce less ethanol. Adaptive evolution offers a potential no GM strategy to generate yeast strains that produce reduced amounts of ethanol [127]. This approach relies on applying a selection pressure that favors a metabolic diversion away from ethanol production. Several reagents can be used to shift yeast carbon metabolism and potentially generate "low alcohol" strains [120]. It is possible that a selection pressure that favors the survival of individuals with enhanced glycerol production will also lead to adaptations resulting in lower ethanol production [128]. However, the results obtained so far suggest that the generation of "low-ethanol" strains by adaptive evolution is not an easy task, and that promising strain isolates may need further improvements in order to create a marketable yeast product. [113]. 
Table 4. Non-conventional yeasts in low alcohol beer production.

\begin{tabular}{|c|c|c|}
\hline Species & Beer Ethanol Content \% Vol & References \\
\hline Lachancea fermentati & $<1.3$ & [129] \\
\hline Saccharomycodes ludwigii & $<0.4$ & [96-98] \\
\hline Torulaspora delbrueckii & $0.5-2.7$ & {$[74,75,100,122]$} \\
\hline Pichia kluyveri & $<0.2$ & {$[84,87,93-95]$} \\
\hline Wickerhamomyces anomalus & $<0.2$ & {$[12,86-88]$} \\
\hline $\begin{array}{c}\text { Zygosaccharomyces rouxii, } \\
\text { Zygosaccharomyces bailii, Zygosaccharomyces kombuchaensis }\end{array}$ & $<0.5$ & {$[98,100,104]$} \\
\hline Hanseniaspora vineae, Hanseniaspora valbyensis & $<0.5$ & {$[26,100]$} \\
\hline Mrakia gelida & $<1.5$ & [110] \\
\hline Candida shehatae & $<0.5$ & [130] \\
\hline Candida zemplinina (Starmerella bacillaris) & $\sim 1.5$ & {$[111,112]$} \\
\hline $\begin{array}{l}\text { Cyberlindnera fabianii (Candida fabianii) } \\
\text { Cyberlindnera mrakii (Williopsis saturnus var. mrakii) }\end{array}$ & $0.6 ; 1.7$ & [107] \\
\hline Pichia kudriavzevii & $<1$ & [107] \\
\hline
\end{tabular}

Similarly, hybridization has been used to improve the fermentation performance, stress tolerance, and flavor profile of brewing strains [48]. However, a set of S. cerevisiae $\times$ S. eubayanus hybrids to increase aroma in lager beers showed variable ethanol production, with some strains producing up to $6 \% v / v$ ethanol and others only $3 \% v / v$ [46]. A natural S. cerevisiae $\times$ S. kudriavzevii hybrid has been described which, related to $S$. cerevisiae, produced more glycerol and potentially less ethanol during wine fermentation at a low temperature of $14{ }^{\circ} \mathrm{C}$ [131]. This suggests that generating hybrids for low-ethanol beer production is a viable option. However, it is important to select and use yeast strains that, in their metabolism, lead to the formation of aromatic compounds that contribute to maintaining organoleptic properties pleasant to consumers.

\subsection{Probiotic Beer}

Functional beers are obtained by enrichment with health-promoting substances, therefore, they are considered as beers giving health benefits, if consumed in moderate amounts. Among the functional beers, an absolute novelty is represented by probiotic beer, obtained by incorporating probiotic microorganisms [132]. Craft beer, which is unpasteurized and unfiltered, can be considered as a new tool to provide beneficial health effects. In contrast, the technologies applied to pasteurized or filtered beers are not suitable for this purpose, as heat or filtration can kill or remove the probiotics, unless the addition of probiotics takes place after pasteurization or filtration. Therefore, because viability is crucial for the effectiveness of probiotics, it could be more suitable to produce craft beer as a probiotic beer, rather than an industrial beer [132]. Most probiotic microorganisms are bacteria, whereas Saccharomyces cerevisiae var. boulardii (synonym S. boulardii) is the only non-conventional yeast used extensively as a probiotic and often marketed as a dietary supplement $[133,134]$. S. boulardii possesses many properties that make it a potential probiotic agent: the survival at body temperature $\left(37^{\circ} \mathrm{C}\right)$, the resistance to stomach acids and bile acids, and the survival to the competitive environment of the intestinal tract $[135,136]$. This yeast, isolated from fruit in Indochina [137], has shown a capability to prevent infectious diarrhea usually caused by bacteria, such as Escherichia coli, and to inhibit invasive properties of Salmonella typhimurium. In addition, it has been very effective against Clostridium difficile in the prevention and treatment of antibiotic-associated diarrhea [138] and may help to eradicate Helicobacter pylori [139]. To present, it is the only yeast species available on the market with probiotic properties. 
In recent studies, $S$. boulardii has had suitable resistance to alcohol and gastrointestinal conditions for probiotic alcoholic beverage development [140]. The use of S. boulardii as a mixed starter with $S$. cerevisiae for craft beer, or as single starter for alcohol-free beer production has been proposed recently [141-143]. In other studies, S. boulardii, used as a single yeast starter culture for brewing, has been shown to produce craft beer with higher antioxidant activity, lower alcohol content, and similar sensory attributes as the craft beer obtained with S. cerevisiae strains. [132,144]. Within this framework, the beer is likely to become a new medium for successful release of probiotic microorganisms, but further research is needed to test the shelf life.

In this type of product, as in other types of unfiltered beers, the presence of yeasts gives the beer its unique taste, but greatly reduces its shelf life, generally to no more than two months; the unfiltered beers are then marketed directly in microbreweries or nearby. In the storage of unfiltered beers, there are changes that, after yeast lysis, can negatively affect its quality (e.g., off-flavor compound production) and probiotic properties. Therefore, in the production of unfiltered beers, such as a probiotic beer, the selection of the yeast strain to be used is very important and must also be studied according to the intracellular substances that are released during the storage of beer, such as antimicrobial and antioxidant compounds.

Other recent studies have looked into the probiotic properties of yeasts isolated from natural environments and from different food matrices not belonging to the species S. boulardii [145-152].

Following the considerations, future studies exploring the isolation of novel brewing yeasts and their potential application in beer probiotication could open interesting biotechnological innovations and new perspectives.

\section{Conclusions}

This study has not only given an overview of the Saccharomyces yeasts normally used in beer production, but also future prospects that biotechnological research could offer in the enhancement of this ultra-millennial drink. The microbrewing phenomenon (craft revolution) and the growing demand for specialty beers has stimulated researchers and brewers to select new yeast strains possessing specific metabolic properties. In particular, the use of non-conventional yeasts can allow the production of innovative products, which are not included in the traditional beer offer, and, at the same time, following new market trends to meet consumer demands.

Author Contributions: Conceptualization, M.I. and B.T.; methodology, B.T., F.C.; software, F.L.; validation, E.S.; data curation, F.C., F.L.; writing-original draft preparation, M.I., B.T; writingreview and editing, M.I., B.T. and F.L.; visualization, F.C.; supervision, E.S. All authors have read and agreed to the published version of the manuscript.

Funding: This research received no external funding.

Institutional Review Board Statement: Not applicable.

Conflicts of Interest: The authors declare no conflict of interest.

\section{References}

1. Iattici, F.; Catallo, M.; Solieri, L. Designing New Yeasts for Craft Brewing: When Natural Biodiversity Meets Biotechnology. Beverages 2020, 6, 3. [CrossRef]

2. Albergaria, H.; Arneborg, N. Dominance of Saccharomyces Cerevisiae in Alcoholic Fermentation Processes: Role of Physiological Fitness and Microbial Interactions. Appl. Microbiol. Biotechnol. 2016, 100, 2035-2046. [CrossRef]

3. Walker, G.M.; Stewart, G.G. Saccharomyces Cerevisiae in the Production of Fermented Beverages. Beverages 2016, 2, 30. [CrossRef]

4. Rainieri, S.; Kodama, Y.; Kaneko, Y.; Mikata, K.; Nakao, Y.; Ashikari, T. Pure and Mixed Genetic Lines of Saccharomyces Bayanus and Saccharomyces Pastorianus and Their Contribution to the Lager Brewing Strain Genome. Appl. Environ. Microbiol. 2006, 72, 3968-3974. [CrossRef]

5. Glover, B. The World Encyclopedia of Beer; Lorenz Books: Dayton, OH, USA, 2001; ISBN 978-0-7548-0933-3. 
6. Salanță, L.C.; Coldea, T.E.; Ignat, M.V.; Pop, C.R.; Tofană, M.; Mudura, E.; Borșa, A.; Pasqualone, A.; Zhao, H. Non-Alcoholic and Craft Beer Production and Challenges. Processes 2020, 8, 1382. [CrossRef]

7. Garavaglia, C.; Swinnen, J. Economics of the Craft Beer Revolution: A Comparative International Perspective. In Economic Perspectives on Craft Beer: A Revolution in the Global Beer Industry; Garavaglia, C., Swinnen, J., Eds.; Springer International Publishing: Cham, Switzerland, 2018; pp. 3-51. ISBN 978-3-319-58235-1.

8. Garavaglia, C. The Emergence of Italian Craft Breweries and the Development of Their Local Identity. In The Geography of Beer: Culture and Economics; Hoalst-Pullen, N., Patterson, M.W., Eds.; Springer International Publishing: Cham, Switzerland, 2020; pp. 135-147. ISBN 978-3-030-41654-6.

9. Jentsch, M. Top-Fermented Beer Specialities in Focus. Brauwelt. Int. 2007, 5, 332-334.

10. Spitaels, F.; Wieme, A.D.; Janssens, M.; Aerts, M.; Daniel, H.-M.; Van Landschoot, A.; De Vuyst, L.; Vandamme, P. The Microbial Diversity of Traditional Spontaneously Fermented Lambic Beer. PLoS ONE 2014, 9, e95384. [CrossRef] [PubMed]

11. Michel, M.; Meier-Dörnberg, T.; Jacob, F.; Methner, F.-J.; Wagner, R.S.; Hutzler, M. Review: Pure Non-Saccharomyces Starter Cultures for Beer Fermentation with a Focus on Secondary Metabolites and Practical Applications. J. Inst. Brew. 2016, 122, 569-587. [CrossRef]

12. Basso, R.F.; Alcarde, A.R.; Portugal, C.B. Could Non-Saccharomyces Yeasts Contribute on Innovative Brewing Fermentations? Food Res. Int. 2016, 86, 112-120. [CrossRef]

13. Stewart, G.G. The Production of Secondary Metabolites with Flavour Potential during Brewing and Distilling Wort Fermentations. Fermentation 2017, 3, 63. [CrossRef]

14. Jolly, N.P.; Varela, C.; Pretorius, I.S. Not Your Ordinary Yeast: Non-Saccharomyces Yeasts in Wine Production Uncovered. FEMS Yeast Res. 2014, 14, 215-237. [CrossRef] [PubMed]

15. Varela, C. The Impact of Non-Saccharomyces Yeasts in the Production of Alcoholic Beverages. Appl. Microbiol. Biotechnol. 2016, 100, 9861-9874. [CrossRef] [PubMed]

16. Domizio, P.; Romani, C.; Lencioni, L.; Comitini, F.; Gobbi, M.; Mannazzu, I.; Ciani, M. Outlining a Future for Non-Saccharomyces Yeasts: Selection of Putative Spoilage Wine Strains to Be Used in Association with Saccharomyces Cerevisiae for Grape Juice Fermentation. Int. J. Food Microbiol. 2011, 147, 170-180. [CrossRef]

17. Lombardi, S.J.; Pannella, G.; Iorizzo, M.; Moreno-Arribas, M.V.; Tremonte, P.; Succi, M.; Sorrentino, E.; Macciola, V.; Di Renzo, M.; Coppola, R. Sequential Inoculum of Hanseniaspora guilliermondii and Saccharomyces Cerevisiae for Winemaking Campanino on an Industrial Scale. World J. Microbiol. Biotechnol. 2018, 34, 161. [CrossRef]

18. Testa, B.; Lombardi, S.J.; Iorizzo, M.; Letizia, F.; Di Martino, C.; Di Renzo, M.; Strollo, D.; Tremonte, P.; Pannella, G.; Ianiro, M.; et al. Use of Strain Hanseniaspora guilliermondii BF1 for Winemaking Process of White Grapes Vitis vinifera Cv Fiano. Eur. Food Res. Technol. 2020, 246, 549-561. [CrossRef]

19. Lombardi, S.J.; Pannella, G.; Iorizzo, M.; Testa, B.; Succi, M.; Tremonte, P.; Sorrentino, E.; Di Renzo, M.; Strollo, D.; Coppola, R. Inoculum Strategies and Performances of Malolactic Starter Lactobacillus plantarum M10: Impact on Chemical and Sensorial Characteristics of Fiano Wine. Microorganisms 2020, 8, 516. [CrossRef] [PubMed]

20. Callejo, M.J.; García Navas, J.J.; Alba, R.; Escott, C.; Loira, I.; González, M.C.; Morata, A. Wort Fermentation and Beer Conditioning with Selected Non-Saccharomyces Yeasts in Craft Beers. Eur. Food Res. Technol. 2019, 245, 1229-1238. [CrossRef]

21. Naseeb, S.; James, S.A.; Alsammar, H.; Michaels, C.J.; Gini, B.; Nueno-Palop, C.; Bond, C.J.; McGhie, H.; Roberts, I.N.; Delneri, D. Saccharomyces jurei Sp. Nov., Isolation and Genetic Identification of a Novel Yeast Species from Quercus robur. Int. J. Syst. Evol. Microbiol. 2017, 67, 2046-2052. [CrossRef]

22. Borneman, A.R.; Pretorius, I.S. Genomic Insights into the Saccharomyces sensu stricto Complex. Genetics 2015, 199, $281-291$. [CrossRef]

23. Stewart, G.G. Saccharomyces Species in the Production of Beer. Beverages 2016, 2, 34. [CrossRef]

24. Stewart, G.G. Harvesting and Cropping Yeast: Flocculation and Centrifugation. In Brewing and Distilling Yeasts; Stewart, G.G., Ed.; Springer International Publishing: Cham, Switzerland, 2017; pp. 259-308. ISBN 978-3-319-69126-8.

25. Petruzzi, L.; Rosaria Corbo, M.; Sinigaglia, M.; Bevilacqua, A. Brewer's Yeast in Controlled and Uncontrolled Fermentations, with a Focus on Novel, Nonconventional, and Superior Strains. Food Rev. Int. 2016, 32, 341-363. [CrossRef]

26. Larroque, M.N.; Carrau, F.; Fariña, L.; Boido, E.; Dellacassa, E.; Medina, K. Effect of Saccharomyces and Non-Saccharomyces Native Yeasts on Beer Aroma Compounds. Int. J. Food Microbiol. 2021, 337, 108953. [CrossRef] [PubMed]

27. Lodolo, E.J.; Kock, J.L.F.; Axcell, B.C.; Brooks, M. The Yeast Saccharomyces Cerevisiae-The Main Character in Beer Brewing. FEMS Yeast Res. 2008, 8, 1018-1036. [CrossRef] [PubMed]

28. Olaniran, A.O.; Maharaj, Y.R.; Pillay, B. Effects of Fermentation Temperature on the Composition of Beer Volatile Compounds, Organoleptic Quality and Spent Yeast Density. Electron. J. Biotechnol. 2011, 14, 5. [CrossRef]

29. Olaniran, A.O.; Hiralal, L.; Mokoena, M.P.; Pillay, B. Flavour-Active Volatile Compounds in Beer: Production, Regulation and Control. J. Inst. Brew. 2017, 123, 13-23. [CrossRef]

30. Pires, E.J.; Teixeira, J.A.; Brányik, T.; Vicente, A.A. Yeast: The Soul of Beer's Aroma-A Review of Flavour-Active Esters and Higher Alcohols Produced by the Brewing Yeast. Appl. Microbiol. Biotechnol. 2014, 98, 1937-1949. [CrossRef]

31. Holt, S.; Miks, M.H.; de Carvalho, B.T.; Foulquié-Moreno, M.R.; Thevelein, J.M. The Molecular Biology of Fruity and Floral Aromas in Beer and Other Alcoholic Beverages. FEMS Microbiol. Rev. 2019, 43, 193-222. [CrossRef] [PubMed]

32. Tyrell, T. Strategies for Reducing Succinic Acid Concentrations in Beer. J. Am. Soc. Brew. Chem. 2014, 72, 246-252. [CrossRef] 
33. Tyrell, T.; Fischer, F. Influencing the Organic Acid Profile of Beer by Application of Adsorbent Materials. J. Inst. Brew. 2014, 120, 459-466. [CrossRef]

34. Tyrell, T.; Reimann, S.; Folz, R.; Harms, D.; Hinrichs, J.; Offer, G. Screening of Brewery Yeast Strains Regarding Organic Acid Profile in Order to Find Low Succinic Acid Producer. Brew. Sci. 2013, 66, 75-84.

35. Bruner, J.; Fox, G. Novel Non-Cerevisiae Saccharomyces Yeast Species Used in Beer and Alcoholic Beverage Fermentations. Fermentation 2020, 6, 116. [CrossRef]

36. Molinet, J.; Cubillos, F.A. Wild Yeast for the Future: Exploring the Use of Wild Strains for Wine and Beer Fermentation. Front. Genet. 2020, 11, 1281. [CrossRef] [PubMed]

37. Budroni, M.; Zara, G.; Ciani, M.; Comitini, F. Saccharomyces and non-Saccharomyces starter yeasts. In Brewing Technology; IntechOpen: London, UK, 2017.

38. Tokpohozin, S.E.; Fischer, S.; Becker, T. Selection of a New Saccharomyces Yeast to Enhance Relevant Sorghum Beer Aroma Components, Higher Alcohols and Esters. Food Microbiol. 2019, 83, 181-186. [CrossRef] [PubMed]

39. Capece, A.; Romaniello, R.; Siesto, G.; Romano, P. Conventional and Non-Conventional Yeasts in Beer Production. Fermentation 2018, 4, 38. [CrossRef]

40. Nguyen, H.-V.; Gaillardin, C. Evolutionary Relationships between the Former Species Saccharomyces uvarum and the Hybrids Saccharomyces bayanus and Saccharomyces pastorianus; Reinstatement of Saccharomyces uvarum (Beijerinck) as a Distinct Species. FEMS Yeast Res. 2005, 5, 471-483. [CrossRef]

41. Libkind, D.; Hittinger, C.T.; Valério, E.; Gonçalves, C.; Dover, J.; Johnston, M.; Gonçalves, P.; Sampaio, J.P. Microbe Domestication and the Identification of the Wild Genetic Stock of Lager-Brewing Yeast. Proc. Natl. Acad. Sci. USA 2011, 108, 14539. [CrossRef]

42. Alexander, W.G.; Peris, D.; Pfannenstiel, B.T.; Opulente, D.A.; Kuang, M.; Hittinger, C.T. Efficient Engineering of Marker-Free Synthetic Allotetraploids of Saccharomyces. Era Synth. Biol. Yeast Filam. Fungi 2016, 89, 10-17. [CrossRef] [PubMed]

43. Hebly, M.; Brickwedde, A.; Bolat, I.; Driessen, M.R.M.; de Hulster, E.A.F.; van den Broek, M.; Pronk, J.T.; Geertman, J.-M.; Daran, J.-M.; Daran-Lapujade, P.S. Cerevisiae $\times$ S. Eubayanus Interspecific Hybrid, the Best of Both Worlds and Beyond. FEMS Yeast Res. 2015, 15. [CrossRef]

44. Krogerus, K.; Magalhães, F.; Vidgren, V.; Gibson, B. New Lager Yeast Strains Generated by Interspecific Hybridization. J. Ind. Microbiol. Biotechnol. 2015, 42, 769-778. [CrossRef]

45. Krogerus, K.; Arvas, M.; De Chiara, M.; Magalhães, F.; Mattinen, L.; Oja, M.; Vidgren, V.; Yue, J.-X.; Liti, G.; Gibson, B. Ploidy Influences the Functional Attributes of de Novo Lager Yeast Hybrids. Appl. Microbiol. Biotechnol. 2016, 100, 7203-7222. [CrossRef]

46. Mertens, S.; Steensels, J.; Saels, V.; De Rouck, G.; Aerts, G.; Verstrepen, K.J. A Large Set of Newly Created Interspecific Saccharomyces Hybrids Increases Aromatic Diversity in Lager Beers. Appl. Environ. Microbiol. 2015, 81, 8202-8214. [CrossRef]

47. Alperstein, L.; Gardner, J.M.; Sundstrom, J.F.; Sumby, K.M.; Jiranek, V. Yeast Bioprospecting versus Synthetic Biology—Which Is Better for Innovative Beverage Fermentation? Appl. Microbiol. Biotechnol. 2020, 104, 1939-1953. [CrossRef]

48. Krogerus, K.; Magalhães, F.; Vidgren, V.; Gibson, B. Novel Brewing Yeast Hybrids: Creation and Application. Appl. Microbiol. Biotechnol. 2017, 101, 65-78. [CrossRef] [PubMed]

49. Vera, L.; Aceña, L.; Guasch, J.; Boqué, R.; Mestres, M.; Busto, O. Characterization and Classification of the Aroma of Beer Samples by Means of an MS E-Nose and Chemometric Tools. Anal. Bioanal. Chem. 2011, 399, 2073-2081. [CrossRef] [PubMed]

50. Ferreira, I.M.; Guido, L.F. Impact of Wort Amino Acids on Beer Flavour: A Review. Fermentation 2018, 4, 23. [CrossRef]

51. Gamero, A.; Dijkstra, A.; Smit, B.; de Jong, C. Aromatic Potential of Diverse Non-Conventional Yeast Species for Winemaking and Brewing. Fermentation 2020, 6, 50. [CrossRef]

52. Li, H.; Liu, F. Changes in Organic Acids during Beer Fermentation. J. Am. Soc. Brew. Chem. 2015, 73, 275-279. [CrossRef]

53. Siebert, K.J. Modeling the Flavor Thresholds of Organic Acids in Beer as a Function of Their Molecular Properties. Food Qual. Prefer. 1999, 10, 129-137. [CrossRef]

54. Steensels, J.; Verstrepen, K.J. Taming Wild Yeast: Potential of Conventional and Nonconventional Yeasts in Industrial Fermentations. Annu. Rev. Microbiol. 2014, 68, 61-80. [CrossRef]

55. Gibson, B.; Geertman, J.; Hittinger, C.; Krogerus, K.; Libkind, D.; Louis, E.J.; Magalhães, F.; Sampaio, J. New Yeasts-New Brews: Modern Approaches to Brewing Yeast Design and Development. FEMS Yeast Res. 2017, 17. [CrossRef]

56. Krogerus, K.; Preiss, R.; Gibson, B. A Unique Saccharomyces Cerevisiae $\times$ Saccharomyces uvarum Hybrid Isolated From Norwegian Farmhouse Beer: Characterization and Reconstruction. Front. Microbiol. 2018, 9, 2253. [CrossRef]

57. Mukai, N.; Nishimori, C.; Fujishige, I.W.; Mizuno, A.; Takahashi, T.; Sato, K. Beer Brewing Using a Fusant between a Sake Yeast and a Brewer's Yeast. J. Biosci. Bioeng. 2001, 91, 482-486. [CrossRef]

58. Choi, B.-J.; Jang, K.-I.; Kim, K.-Y. Fermentation Characteristics of Brewing Yeast HCS with Glucoamylase Expression by Rare Mating and Beer Analysis. Food Sci. Biotechnol. 2002, 11, 34-39.

59. Sato, M.; Kishimoto, M.; Watari, J.; Takashio, M. Breeding of Brewer's Yeast by Hybridization between a Top-Fermenting Yeast Saccharomyces Cerevisiae and a Cryophilic Yeast Saccharomyces bayanus. J. Biosci. Bioeng. 2002, 93, 509-511. [CrossRef]

60. Sanchez, R.G.; Solodovnikova, N.; Wendland, J. Breeding of Lager Yeast with Saccharomyces Cerevisiae Improves Stress Resistance and Fermentation Performance. Yeast 2012, 29, 343-355. [CrossRef]

61. Steensels, J.; Meersman, E.; Snoek, T.; Saels, V.; Verstrepen, K.J. Large-Scale Selection and Breeding to Generate Industrial Yeasts with Superior Aroma Production. Appl. Environ. Microbiol. 2014, 80, 6965-6975. [CrossRef] [PubMed] 
62. Padilla, B.; Gil, J.V.; Manzanares, P. Past and Future of Non-Saccharomyces Yeasts: From Spoilage Microorganisms to Biotechnological Tools for Improving Wine Aroma Complexity. Front. Microbiol. 2016, 7, 411. [CrossRef] [PubMed]

63. Benito, S.; Ruiz, J.; Belda, I.; Kiene, F.; Beisert, B.; Navascués, E.; Marquina, D.; Calderón, F.; Santos, A.; Rauhut, D. Application of non-Saccharomyces yeasts in wine production. In Non-Conventional Yeasts: From Basic Research to Application; Springer: Cham, Switzerland, 2019; pp. 75-89.

64. Estela-Escalante, W.D. Perspectives and Uses of Non-Saccharomyces Yeasts in Fermented Beverages. In Frontiers and New Trends in the Science of Fermented Food and Beverages; IntechOpen: London, UK, 2018.

65. Callejo, M.J.; Tesfaye, W.; González, M.C.; Morata, A. Craft Beers: Current Situation and Future Trends. In New Advances on Fermentation Processes; IntechOpen: London, UK, 2019.

66. Colomer, M.S.; Funch, B.; Forster, J. The Raise of Brettanomyces Yeast Species for Beer Production. Curr. Opin. Biotechnol. 2019, 56, 30-35. [CrossRef] [PubMed]

67. Crauwels, S.; Steensels, J.; Aerts, G.; Willems, K.; Verstrepen, K.; Lievens, B. Brettanomyces Bruxellensis, Essential Contributor in Spontaneous Beer Fermentations Providing Novel Opportunities for the Brewing Industry. BrewingScience 2015, 68, 110-121.

68. Steensels, J.; Daenen, L.; Malcorps, P.; Derdelinckx, G.; Verachtert, H.; Verstrepen, K.J. Brettanomyces Yeasts-From Spoilage Organisms to Valuable Contributors to Industrial Fermentations. Int. J. Food Microbiol. 2015, 206, 24-38. [CrossRef] [PubMed]

69. García, M.; Esteve-Zarzoso, B.; Arroyo, T. Non-Saccharomyces Yeasts: Biotechnological Role for Wine Production. Grape Wine Biotechnol. 2016, 249-271.

70. Johnson, E.A. Biotechnology of Non-Saccharomyces Yeasts-The Ascomycetes. Appl. Microbiol. Biotechnol. 2013, $97,503-517$. [CrossRef] [PubMed]

71. Iorizzo, M.; Testa, B.; Lombardi, S.J.; García-Ruiz, A.; Muñoz-González, C.; Bartolomé, B.; Moreno-Arribas, M.V. Selection and Technological Potential of Lactobacillus plantarum Bacteria Suitable for Wine Malolactic Fermentation and Grape Aroma Release. LWT 2016, 73, 557-566. [CrossRef]

72. Tolosa, J.J.M.; Prieto, S.M. Chapter 25-Non-Saccharomyces Yeasts: An Enzymatic Unexplored World to be Exploited. In Enzymes in Food Biotechnology; Kuddus, M., Ed.; Academic Press: San Diego, CA, USA, 2019; pp. 433-450. ISBN 978-0-12-813280-7.

73. Piló, F.B.; Carvajal-Barriga, E.J.; Guamán-Burneo, M.C.; Portero-Barahona, P.; Dias, A.M.M.; de Freitas, L.F.D.; Gomes, F.d.C.O.; Rosa, C.A. Saccharomyces Cerevisiae Populations and Other Yeasts Associated with Indigenous Beers (Chicha) of Ecuador. Braz. J. Microbiol. 2018, 49, 808-815. [CrossRef]

74. Canonico, L.; Agarbati, A.; Comitini, F.; Ciani, M. Torulaspora delbrueckii in the Brewing Process: A New Approach to Enhance Bioflavour and to Reduce Ethanol Content. Food Microbiol. 2016, 56, 45-51. [CrossRef]

75. Michel, M.; Kopecká, J.; Meier-Dörnberg, T.; Zarnkow, M.; Jacob, F.; Hutzler, M. Screening for New Brewing Yeasts in the Non-Saccharomyces Sector with Torulaspora delbrueckii as Model. Yeast 2016, 33, 129-144. [CrossRef]

76. Ravasio, D.; Carlin, S.; Boekhout, T.; Groenewald, M.; Vrhovsek, U.; Walther, A.; Wendland, J. Adding Flavor to Beverages with Non-Conventional Yeasts. Fermentation 2018, 4, 15. [CrossRef]

77. Sannino, C.; Mezzasoma, A.; Buzzini, P.; Turchetti, B. Non-conventional Yeasts for Producing Alternative Beers. In NonConventional Yeasts: From Basic Research to Application; Sibirny, A., Ed.; Springer International Publishing: Cham, Switzerland, 2019; pp. 361-388. ISBN 978-3-030-21110-3.

78. Roudil, L.; Russo, P.; Berbegal, C.; Albertin, W.; Spano, G.; Capozzi, V. Non-Saccharomyces Commercial Starter Cultures: Scientific Trends, Recent Patents and Innovation in the Wine Sector. Recent Pat. Food Nutr. Agric. 2019, 11, 27-39. [CrossRef]

79. Toh, D.W.K.; Chua, J.Y.; Lu, Y.; Liu, S.Q. Evaluation of the Potential of Commercial Non-Saccharomyces Yeast Strains of Torulaspora delbrueckii and Lachancea thermotolerans in Beer Fermentation. Int. J. Food Sci. Technol. 2020, 55, 2049-2059. [CrossRef]

80. Colomer, M.S.; Chailyan, A.; Fennessy, R.T.; Olsson, K.F.; Johnsen, L.; Solodovnikova, N.; Forster, J. Assessing Population Diversity of Brettanomyces Yeast Species and Identification of Strains for Brewing Applications. Front. Microbiol. 2020, 11, 637. [CrossRef]

81. Schifferdecker, A.J.; Dashko, S.; Ishchuk, O.P.; Piškur, J. The Wine and Beer Yeast Dekkera bruxellensis. Yeast 2014, 31, 323-332. [CrossRef]

82. Ciosek, A.; Rusiecka, I.; Poreda, A. Sour Beer Production: Impact of Pitching Sequence of Yeast and Lactic Acid Bacteria. J. Inst. Brew. 2020, 126, 53-58. [CrossRef]

83. Daenen, L.; Sterckx, F.; Delvaux, F.R.; Verachtert, H.; Derdelinckx, G. Evaluation of the Glycoside Hydrolase Activity of a Brettanomyces Strain on Glycosides from Sour Cherry (Prunus cerasus L.) Used in the Production of Special Fruit Beers. FEMS Yeast Res. 2008, 8, 1103-1114. [CrossRef] [PubMed]

84. Bokulich, N.A.; Bamforth, C.W.; Mills, D.A. Brewhouse-Resident Microbiota Are Responsible for Multi-Stage Fermentation of American Coolship Ale. PLoS ONE 2012, 7, e35507. [CrossRef]

85. Lentz, M.; Putzke, T.; Hessler, R.; Luman, E. Genetic and Physiological Characterization of Yeast Isolated from Ripe Fruit and Analysis of Fermentation and Brewing Potential. J. Inst. Brew. 2014, 120, 559-564. [CrossRef]

86. Spitaels, F.; Wieme, A.D.; Janssens, M.; Aerts, M.; Van Landschoot, A.; De Vuyst, L.; Vandamme, P. The Microbial Diversity of an Industrially Produced Lambic Beer Shares Members of a Traditionally Produced One and Reveals a Core Microbiota for Lambic Beer Fermentation. Food Microbiol. 2015, 49, 23-32. [CrossRef]

87. Holt, S.; Mukherjee, V.; Lievens, B.; Verstrepen, K.J.; Thevelein, J.M. Bioflavoring by Non-Conventional Yeasts in Sequential Beer Fermentations. Food Microbiol. 2018, 72, 55-66. [CrossRef] [PubMed] 
88. De Roos, J.; Vandamme, P.; De Vuyst, L. Wort Substrate Consumption and Metabolite Production During Lambic Beer Fermentation and Maturation Explain the Successive Growth of Specific Bacterial and Yeast Species. Front. Microbiol. 2018, 9, 2763. [CrossRef] [PubMed]

89. Wang, J.; Liu, L.; Ball, T.; Yu, L.; Li, Y.; Xing, F. Revealing a 5,000-y-Old Beer Recipe in China. Proc. Natl. Acad. Sci. USA 2016, 113, 6444-6448. [CrossRef] [PubMed]

90. Tokpohozin, S.E.; Lauterbach, A.; Fischer, S.; Behr, J.; Sacher, B.; Becker, T. Phenotypical and Molecular Characterization of Yeast Content in the Starter of "Tchoukoutou”, a Beninese African Sorghum Beer. Eur. Food Res. Technol. 2016, 242, 2147-2160. [CrossRef]

91. Domizio, P.; House, J.F.; Joseph, C.M.L.; Bisson, L.F.; Bamforth, C.W. Lachancea Thermotolerans as an Alternative Yeast for the Production of Beer. J. Inst. Brew. 2016, 122, 599-604. [CrossRef]

92. Zdaniewicz, M.; Satora, P.; Pater, A.; Bogacz, S. Low Lactic Acid-Producing Strain of Lachancea Thermotolerans as a New Starter for Beer Production. Biomolecules 2020, 10, 256. [CrossRef]

93. N'guessan, K.F.; Brou, K.; Jacques, N.; Casaregola, S.; Dje, K.M. Identification of Yeasts during Alcoholic Fermentation of Tchapalo, a Traditional Sorghum Beer from Côte d'Ivoire. Antonie Van Leeuwenhoek 2011, 99, 855-864. [CrossRef]

94. Saerens, S.; Swiegers, J.H. Enhancement of Beer Flavor by a Combination of Pichia Yeast and Different Hop Varieties. WO2013030398A1, 7 March 2013.

95. Saerens, S.; Swiegers, J.H. Production of Low-Alcohol or Alcohol-Free Beer with Pichia Kluyveri Yeast Strains. WO2014135673A2, 12 September 2014.

96. Brányik, T.; Vicente, A.A.; Dostálek, P.; Teixeira, J.A. A Review of Flavour Formation in Continuous Beer Fermentations. J. Inst. Brew. 2008, 114, 3-13. [CrossRef]

97. Liu, Y.; Li, H.; Du, J. Non-Alcoholic Beer Production by Saccharomycodes ludwigii. Food Sci. 2011, 32, $186-190$.

98. De Francesco, G.; Turchetti, B.; Sileoni, V.; Marconi, O.; Perretti, G. Screening of New Strains of Saccharomycodes ludwigii and Zygosaccharomyces rouxii to Produce Low-alcohol Beer. J. Inst. Brew. 2015, 121, 113-121. [CrossRef]

99. Gibson, B.; Liti, G. Saccharomyces pastorianus: Genomic Insights Inspiring Innovation for Industry. Yeast 2015, 32, 17-27. [CrossRef]

100. Bellut, K.; Michel, M.; Zarnkow, M.; Hutzler, M.; Jacob, F.; De Schutter, D.P.; Daenen, L.; Lynch, K.M.; Zannini, E.; Arendt, E.K. Application of Non-Saccharomyces Yeasts Isolated from Kombucha in the Production of Alcohol-Free Beer. Fermentation 2018, 4, 66. [CrossRef]

101. Azzolini, M.; Fedrizzi, B.; Tosi, E.; Finato, F.; Vagnoli, P.; Scrinzi, C.; Zapparoli, G. Effects of Torulaspora delbrueckii and Saccharomyces Cerevisiae Mixed Cultures on Fermentation and Aroma of Amarone Wine. Eur. Food Res. Technol. 2012, 235, 303-313. [CrossRef]

102. Tataridis, P.; Kanellis, A.; Logothetis, S.; Nerantzis, E. Use of Non-Saccharomyces Torulaspora delbrueckii Yeast Strains in Winemaking and Brewing. Matica Srp. J. Nat. Sci. 2013, 124, 415-426. [CrossRef]

103. Einfalt, D. Barley-Sorghum Craft Beer Production with Saccharomyces Cerevisiae, Torulaspora delbrueckii and Metschnikowia pulcherrima Yeast Strains. Eur. Food Res. Technol. 2021, 247, 385-393. [CrossRef]

104. Sohrabvandi, S.; Razavi, S.H.; Mousavi, S.M.; Mortazavian, A.; Rezaei, K. Application of Saccharomyces rouxii for the Production of Non-Alcoholic Beer. Food Sci. Biotechnol. 2009, 18, 1132-1137.

105. Bourbon-Melo, N.; Palma, M.; Rocha, M.P.; Ferreira, A.; Bronze, M.R.; Elias, H.; Sá-Correia, I. Use of Hanseniaspora guilliermondii and Hanseniaspora opuntiae to Enhance the Aromatic Profile of Beer in Mixed-Culture Fermentation with Saccharomyces Cerevisiae. Food Microbiol. 2021, 95, 103678. [CrossRef] [PubMed]

106. Liu, S.-Q.; Hui Quek, A.Y. Evaluation of Beer Fermentation with a Novel Yeast Williopsis saturnus. Food Technol. Biotechnol. 2016, 54, 403-412. [CrossRef] [PubMed]

107. Van Rijswijck, I.M.H.; Wolkers-Rooijackers, J.C.M.; Abee, T.; Smid, E.J. Performance of Non-Conventional Yeasts in Co-Culture with Brewers' Yeast for Steering Ethanol and Aroma Production. Microb. Biotechnol. 2017, 10, 1591-1602. [CrossRef] [PubMed]

108. N'Guessan, F.K.; N’Dri, D.Y.; Camara, F.; Djè, M.K. Saccharomyces Cerevisiae and Candida tropicalis as Starter Cultures for the Alcoholic Fermentation of Tchapalo, a Traditional Sorghum Beer. World J. Microbiol. Biotechnol. 2010, 26, 693-699. [CrossRef]

109. Alloue-Boraud, W.A.M.; N'Guessan, K.F.; Djeni, N.T.; Hiligsmann, S.; Djè, K.M.; Delvigne, F. Fermentation Profile of Saccharomyces Cerevisiae and Candida tropicalis as Starter Cultures on Barley Malt Medium. J. Food Sci. Technol. 2015, 52, 5236-5242. [CrossRef]

110. De Francesco, G.; Sannino, C.; Sileoni, V.; Marconi, O.; Filippucci, S.; Tasselli, G.; Turchetti, B. Mrakia Gelida in Brewing Process: An Innovative Production of Low Alcohol Beer Using a Psychrophilic Yeast Strain. Food Microbiol. 2018, 76, 354-362. [CrossRef]

111. Estela-Escalante, W.D.; Moscosa-Santillán, M.; González-Ramírez, J.E.; Rosales-Mendoza, S. Evaluation of the Potential Production of Ethanol by Candida zemplinina Yeast with Regard to Beer Fermentation. J. Am. Soc. Brew. Chem. 2017, 75, $130-135$.

112. Estela-Escalante, W.D.; Rosales-Mendoza, S.; Moscosa-Santillán, M.; González-Ramírez, J.E. Evaluation of the Fermentative Potential of Candida zemplinina Yeasts for Craft Beer Fermentation. J. Inst. Brew. 2016, 122, 530-535. [CrossRef]

113. Varela, J.; Varela, C. Microbiological Strategies to Produce Beer and Wine with Reduced Ethanol Concentration. Curr. Opin. Biotechnol. 2019, 56, 88-96. [CrossRef] [PubMed]

114. Andrés-Iglesias, C.; Montero, O.; Sancho, D.; Blanco, C.A. New Trends in Beer Flavour Compound Analysis. J. Sci. Food Agric. 2015, 95, 1571-1576. [CrossRef]

115. Sohrabvandi, S.; Mousavi, S.M.; Razavi, S.H.; Mortazavian, A.M.; Rezaei, K. Alcohol-Free Beer: Methods of Production, Sensorial Defects, and Healthful Effects. Food Rev. Int. 2010, 26, 335-352. [CrossRef] 
116. Blanco, C.A.; Andrés-Iglesias, C.; Montero, O. Low-Alcohol Beers: Flavor Compounds, Defects, and Improvement Strategies. Crit. Rev. Food Sci. Nutr. 2016, 56, 1379-1388. [CrossRef] [PubMed]

117. Muller, C.; Neves, L.E.; Gomes, L.; Guimarães, M.; Ghesti, G. Processes for Alcohol-Free Beer Production: A Review. Food Sci. Technol. 2020, 40, 273-281. [CrossRef]

118. Montanari, L.; Marconi, O.; Mayer, H.; Fantozzi, P. Chapter 6-Production of Alcohol-Free Beer. In Beer in Health and Disease Prevention; Preedy, V.R., Ed.; Academic Press: San Diego, CA, USA, 2009; pp. 61-75. ISBN 978-0-12-373891-2.

119. Brányik, T.; Silva, D.P.; Baszczyňski, M.; Lehnert, R.; Almeida e Silva, J.B. A Review of Methods of Low Alcohol and Alcohol-Free Beer Production. J. Food Eng. 2012, 108, 493-506. [CrossRef]

120. Kutyna, D.R.; Varela, C.; Henschke, P.A.; Chambers, P.J.; Stanley, G.A. Microbiological Approaches to Lowering Ethanol Concentration in Wine. Trends Food Sci. Technol. 2010, 21, 293-302. [CrossRef]

121. Kochláňová, T.; Kij, D.; Kopecká, J.; Kubizniaková, P.; Matoulková, D. Non-Saccharomyces Yeasts and Their Importance in the Brewing Industry Part I-Brettanomyces (Dekkera). Kvas. Prům. 2016, 62, 198-205. [CrossRef]

122. Contreras, A.; Hidalgo, C.; Schmidt, S.; Henschke, P.; Curtin, C.; Varela, C. The Application of Non-Saccharomyces Yeast in Fermentations with Limited Aeration as a Strategy for the Production of Wine with Reduced Alcohol Content. Int. J. Food Microbiol. 2015, 205, 7-15. [CrossRef]

123. Jiang, Z.; Yang, B.; Liu, X.; Zhang, S.; Shan, J.; Liu, J.; Wang, X. A Novel Approach for the Production of a Non-Alcohol Beer $(\leq 0.5 \% \mathrm{Abv})$ by a Combination of Limited Fermentation and Vacuum Distillation. J. Inst. Brew. 2017, 123, 533-536. [CrossRef]

124. Jackowski, M.; Trusek, A. Non-Alcoholic Beer Production-An Overview. Pol. J. Chem. Technol. 2018, 20, 32-38. [CrossRef]

125. Meier-Dörnberg, T.; Hutzler, M. Alcohol-Free Wheat Beer with Maltose Negative Yeast Strain Saccharomycodes ludwigii. In Proceedings of the Conference: Young Scientists Symposium on Malting, Brewing and Distilling, Ghent, Belgium; 2014 ; Volume 3.

126. Bellut, K.; Arendt, E.K. Chance and Challenge: Non-Saccharomyces Yeasts in Nonalcoholic and Low Alcohol Beer Brewing-A Review. J. Am. Soc. Brew. Chem. 2019, 77, 77-91. [CrossRef]

127. Strejc, J.; Siř́išt'ová, L.; Karabín, M.; Almeida e Silva, J.B.; Brányik, T. Production of Alcohol-Free Beer with Elevated Amounts of Flavouring Compounds Using Lager Yeast Mutants. J. Inst. Brew. 2013, 119, 149-155. [CrossRef]

128. Tilloy, V.; Ortiz-Julien, A.; Dequin, S. Reduction of Ethanol Yield and Improvement of Glycerol Formation by Adaptive Evolution of the Wine Yeast Saccharomyces Cerevisiae under Hyperosmotic Conditions. Appl. Environ. Microbiol. 2014, 80, 2623. [CrossRef] [PubMed]

129. Bellut, K.; Krogerus, K.; Arendt, E.K. Lachancea Fermentati Strains Isolated from Kombucha: Fundamental Insights, and Practical Application in Low Alcohol Beer Brewing. Front. Microbiol. 2020, 11, 764. [CrossRef] [PubMed]

130. Li, H.; Liu, Y.; Zhang, W. Method for Manufacturing Alcohol-Free Beer through Candida shehatae. CN102220198B, 06 February 2013.

131. Arroyo-López, F.N.; Pérez-Torrado, R.; Querol, A.; Barrio, E. Modulation of the Glycerol and Ethanol Syntheses in the Yeast Saccharomyces kudriavzevii Differs from That Exhibited by Saccharomyces Cerevisiae and Their Hybrid. Food Microbiol. 2010, 27, 628-637. [CrossRef]

132. Capece, A.; Romaniello, R.; Pietrafesa, A.; Siesto, G.; Pietrafesa, R.; Zambuto, M.; Romano, P. Use of Saccharomyces Cerevisiae var. boulardii in Co-Fermentations with S. Cerevisiae for the Production of Craft Beers with Potential Healthy Value-Added. Int. J. Food Microbiol. 2018, 284, 22-30. [CrossRef]

133. McFarland, L.V. Systematic Review and Meta-Analysis of Saccharomyces boulardii in Adult Patients. World J. Gastroenterol. 2010, 16, 2202-2222. [CrossRef]

134. Im, E.; Pothoulakis, C. Recent Advances in Saccharomyces boulardii Research. Intest. Microbiota Equilib. Disord. 2010, 34, S62-S70. [CrossRef]

135. Czerucka, D.; Piche, T.; Rampal, P. Review Article: Yeast as Probiotics-Saccharomyces boulardii. Aliment Pharmacol. 2007, 26, 767-778. [CrossRef]

136. Kelesidis, T.; Pothoulakis, C. Efficacy and Safety of the Probiotic Saccharomyces boulardii for the Prevention and Therapy of Gastrointestinal Disorders. Ther. Adv. Gastroenterol. 2011, 5, 111-125. [CrossRef] [PubMed]

137. McCullough, M.J.; Clemons, K.V.; McCusker, J.H.; Stevens, D.A. Species Identification and Virulence Attributes of Saccharomyces boulardii. J. Clin. Microbiol. 1998, 36, 2613. [CrossRef]

138. Kabbani, T.A.; Pallav, K.; Dowd, S.E.; Villafuerte-Galvez, J.; Vanga, R.R.; Castillo, N.E.; Hansen, J.; Dennis, M.; Leffler, D.A.; Kelly, C.P. Prospective Randomized Controlled Study on the Effects of Saccharomyces boulardii CNCM I-745 and Amoxicillin-Clavulanate or the Combination on the Gut Microbiota of Healthy Volunteers. Gut Microbes 2017, 8, 17-32. [CrossRef] [PubMed]

139. Greenhill, C. Probiotic Helps to Eradicate H. Pylori. Nat. Rev. Gastroenterol. Hepatol. 2010, 7, 362. [CrossRef]

140. De Paula, B.P.; Chávez, D.W.H.; Lemos Junior, W.J.F.; Guerra, A.F.; Corrêa, M.F.D.; Pereira, K.S.; Coelho, M.A.Z. Growth Parameters and Survivability of Saccharomyces boulardii for Probiotic Alcoholic Beverages Development. Front. Microbiol. 2019, 10, 2092. [CrossRef]

141. Senkarcinova, B.; Graça Dias, I.A.; Nespor, J.; Branyik, T. Probiotic Alcohol-Free Beer Made with Saccharomyces Saccharomyces Cerevisiae var. boulardii. LWT 2019, 100, 362-367. [CrossRef]

142. Mulero-Cerezo, J.; Briz-Redón, Á.; Serrano-Aroca, Á. Saccharomyces Cerevisiae var. boulardii: Valuable Probiotic Starter for Craft Beer Production. Appl. Sci. 2019, 9, 3250. [CrossRef] 
143. De Paula, B.P.; de Souza Lago, H.; Firmino, L.; Júnior, W.J.F.L.; Corrêa, M.F.D.; Guerra, A.F.; Pereira, K.S.; Coelho, M.A.Z. Technological Features of Saccharomyces Cerevisiae var. boulardii for Potential Probiotic Wheat Beer Development. LWT 2021, 135, 110233. [CrossRef]

144. Ramírez-Cota, G.Y.; López-Villegas, E.O.; Jiménez-Aparicio, A.R.; Hernández-Sánchez, H. Modeling the Ethanol Tolerance of the Probiotic Yeast Saccharomyces Cerevisiae var. boulardii CNCM I-745 for Its Possible Use in a Functional Beer. Probiotics Antimicrob. Proteins 2021, 13, 187-194. [CrossRef]

145. Agarbati, A.; Canonico, L.; Marini, E.; Zannini, E.; Ciani, M.; Comitini, F. Potential Probiotic Yeasts Sourced from Natural Environmental and Spontaneous Processed Foods. Foods 2020, 9, 287. [CrossRef] [PubMed]

146. Fernández-Pacheco, P.; Cueva, C.; Arévalo-Villena, M.; Moreno-Arribas, M.V.; Pérez, A.B. Saccharomyces Cerevisiae and Hanseniaspora Osmophila Strains as Yeast Active Cultures for Potential Probiotic Applications. Food Funct. 2019, 10, 4924-4931. [CrossRef] [PubMed]

147. Perricone, M.; Bevilacqua, A.; Corbo, M.R.; Sinigaglia, M. Technological Characterization and Probiotic Traits of Yeasts Isolated from Altamura Sourdough to Select Promising Microorganisms as Functional Starter Cultures for Cereal-Based Products. Food Microbiol. 2014, 38, 26-35. [CrossRef]

148. Arevalo-Villena, M.; Briones-Perez, A.; Corbo, M.R.; Sinigaglia, M.; Bevilacqua, A. Biotechnological Application of Yeasts in Food Science: Starter Cultures, Probiotics and Enzyme Production. J. Appl. Microbiol. 2017, 123, 1360-1372. [CrossRef]

149. Pennacchia, C.; Blaiotta, G.; Pepe, O.; Villani, F. Isolation of Saccharomyces Cerevisiae Strains from Different Food Matrices and Their Preliminary Selection for a Potential Use as Probiotics. J. Appl. Microbiol. 2008, 105, 1919-1928. [CrossRef]

150. Ochangco, H.S.; Gamero, A.; Smith, I.M.; Christensen, J.E.; Jespersen, L.; Arneborg, N. In Vitro Investigation of Debaryomyces hansenii Strains for Potential Probiotic Properties. World J. Microbiol. Biotechnol. 2016, 32, 141. [CrossRef] [PubMed]

151. Ogunremi, O.R.; Sanni, A.I.; Agrawal, R. Probiotic Potentials of Yeasts Isolated from Some Cereal-Based Nigerian Traditional Fermented Food Products. J. Appl. Microbiol. 2015, 119, 797-808. [CrossRef] [PubMed]

152. Binetti, A.; Carrasco, M.; Reinheimer, J.; Suárez, V. Yeasts from Autochthonal Cheese Starters: Technological and Functional Properties. J. Appl. Microbiol. 2013, 115, 434-444. [CrossRef] [PubMed] 